\title{
Study on Marketing Strategy System of SMEs under Internet Background
}

\author{
Yongyue Jin \\ School of Business Administration, South China University of Technology, Guangzhou, China \\ Email: jinyongyue@foxmail.com
}

How to cite this paper: Jin, Y.Y. (2018) Study on Marketing Strategy System of SMEs under Internet Background. American Journal of Industrial and Business Management, 8, 638-644. https://doi.org/10.4236/ajibm.2018.83042

Received: February 28, 2018

Accepted: March 20, 2018

Published: March 23, 2018

Copyright $\odot 2018$ by authors and Scientific Research Publishing Inc. This work is licensed under the Creative Commons Attribution International License (CC BY 4.0).

http://creativecommons.org/licenses/by/4.0/

(c) (i) Open Access

\begin{abstract}
Generally speaking, small and medium-sized enterprises (SMEs) have common problems in marketing strategy formulation and strategy implementation, such as lagging marketing concept and single marketing mode and so on [1]. The incompleteness of marketing strategy system seriously restricts the leapfrog development and sustainable development of SMEs. Problems in the implementation of SME marketing strategy mainly reflect the lack of professional Internet marketing personnel reserved, the lack of mature concept of mobile Internet marketing and good use of mobile Internet marketing [2]. According to the problems existing in the marketing of SMEs in our country, the marketing strategy optimization of SMEs should be promoted in the aspects of cultivating and introducing mobile Internet marketing professionals, updating the concept of mobile Internet marketing, using the Internet to put into operation accurately and using Internet tools to build core competitiveness [3]. First this article introduces the definition of SMEs and the importance of SMEs for the national economy, and then collates and summarizes the problems faced by SMEs in China in the context of the Internet and provides solutions to these problems, which are also the main contribution of this article.
\end{abstract}

\section{Keywords}

Small and Medium-Sized Enterprises, Marketing, Strategic System, Current Situation Analysis, Countermeasure Research

\section{Introduction}

For small and medium-sized enterprises, they are classified according to the differences in the development of the industry, the scale of enterprises, the number of employees and the income of the enterprises and so on. For example, the 
NDRC, the Ministry of Finance, the Ministry of Industry and Information Technology issued the "Notice on Printing Standard Provisions for Small and Medium Sized Enterprises", classifying industrial enterprises with less than 1000 employees and annual sales income of 400 million yuan as the type of small and medium-sized enterprises. SMEs play an important role in the national economy, and SMEs also play an irreplaceable role in promoting economic growth, promoting innovation, increasing taxes, attracting employment and improving people's livelihood. SMEs provided more than $50 \%$ of tax revenue, created more than $60 \%$ of their GDP, completed more than $70 \%$ of invention patents, and provided more than $80 \%$ of urban jobs, accounting for more than $99 \%$ of the total number of enterprises [4].

In the era of Internet+, the various elements have changed. The Internet has promoted the optimization and integration of the production elements and the ability to innovate, which will change the scale agglomeration effect of the past and need more to develop effective markets and achieve accurate users [5]. The future of corporate marketing will pay more attention to the use of big data, enhancing value creation, enhancing customer experience. In the era of Internet+, SMEs marketing needs more innovation in concepts, theories, markets, technologies, methods, strategies, organizations, rules and so on. This means that SMEs also face more challenges. SMEs must adhere to advancing with the times, persisting in innovation, identifying problems in their own development, and formulating suitable marketing strategies for their own development so that they can develop in an internationalized market in the new era, and maintain its own advantages and gain long-term development.

This paper collates and summarizes the problems that restrict the development of SMEs in the era of Internet+, such as lack of mobile internet marketing personnel reserved, lack of mature concept of mobile internet marketing, and use of mobile internet marketing incomprehensive. And this paper finally provides corresponding solutions one by one. However, at the same time, due to the limited space, this article does not describe these solutions in detail. And the impacts of the Internet on various industries are not the same, so the problems faced may be different. Therefore, the specific implementation of these methods should be based on specific analysis of the problem.

\section{Necessity of Innovating Marketing Strategy of SMEs}

SMEs occupy an important position in the national economy and are an important growth point for the national economy and have gradually become the main force for the development of social productive forces. They play an important role in settling employment and are an important foundation for social stability [6]. Many SMEs are labor-intensive enterprises that require relatively low skills of workers and can widely absorb labor, create employment opportunities and promote social stability. They also occupy the dominant position in rural economy and play an important role in increasing farmers' income, promoting agricultural development and rural economic development. With the popularization 
of the Internet and the development of economic globalization, SMEs have become an important force in the export of products and have been active in the international market. Accelerating the development of SMEs and solving the existing marketing problems in SMEs are of great significance to the sustained and steady economic growth.

SMEs marketing activities are part of SMEs management, relating to the economic benefits of SMEs. Through marketing, companies can fully understand the market, understand the needs of consumers, and develop products, sales methods, pricing and other strategies to form a market-oriented management to meet consumer demand for products and services, so that they can increase the income of SMEs. However, these traditional marketing strategies need to implement an enterprise marketing strategy in the context of the Internet with another new means.

\section{Characteristics and Existing Problems of SMEs Marketing under Background of Internet}

At present, judging from the present situation of the marketing development of all major SMEs in China, they have the following characteristics: 1) SMEs are small in size but strong in environmental adaptability. SMEs can timely adjust their own industrial structure according to changes in the market and change the direction of production so as to adapt to changes in market demand. 2) SMEs have a larger business scope in the market. Although the technology is single, more attention is paid to the application of professional technologies. 3) SMEs marketing model is more flexible than large enterprises in technical innovation, good at applying a variety of new technology, and can promote product replacement to the greatest extent possible to meet the needs of the market [7].

At the same time, marketing has gradually been widely accepted by business owners, and marketing of corporate products gradually shifts from the traditional to the new marketing concept in the Internet context, and some SMEs in our country have started to learn how to use new marketing methods to arm themselves. However, on the whole, there are still some enterprises that do not make enough market development efforts, and lack of understanding of marketing and information channels. They only view marketing as a general marketing. In the actual marketing process, they are embodied as:

1) Lack of Mobile Internet Marketing Personnel Reserved

From the point of view of talent's role in enterprise development, talent is a driving force for enterprise development, but also a source of enterprise development. The development of SMEs mobile Internet marketing in China also need talent [8]. With the support of personnel, the further development of mobile Internet marketing is possible. The talent here refers to those who have the knowledge and ability of mobile Internet marketing professionals. However, deep into China's SMEs mobile Internet marketing inside, we can find that many companies do not attach importance to the cultivation and introduction of 
mobile Internet marketing personnel. Most of the Internet marketers within the enterprise just have the experience of traditional marketing, and this also has a great relationship to time of development of mobile Internet marketing. Under these unfavorable factors, the marketing ability of mobile Internet marketers in SMEs in China is lacking, which greatly restricts the development of SME mobile network marketing.

2) Lack of Mature Concept of Mobile Internet Marketing

Driven by the boom of mobile internet, in order to realize the development of mobile Internet marketing, the SMEs in China need to clearly understand the concept of mobile Internet marketing and use it as a guide to promote the modernization of enterprises. However, from the concept of mobile Internet marketing in China's SMEs, many traditional marketing concepts are used, and some SMEs are based on traditional marketing, and then carry out mobile Internet marketing [9]. These largely reflect SMEs in China's understanding of the mobile Internet economy is not in place. From the perspective of the development of these SMEs, mobile phones and other mobile terminals as the basis for further implementation of the corresponding marketing campaign is the so-called mobile Internet marketing. However, these are plain understandings of mobile Internet marketing, which will mislead the development of SMEs in the level of concept development and urge some enterprises to follow the traditional marketing ideas in the process of mobile Internet marketing development, thus limiting the effective development of enterprises.

3) Use of Mobile Internet Marketing Incomprehensive

To some extent, accuracy is an important feature of mobile internet marketing. If mobile internet marketing has a high degree of accuracy, the accurate marketing of an enterprise can also be well implemented and the information can be delivered to customers anytime, anywhere [10]. It can enhance customer viscosity, retain customers, improve the spread of word of mouth, good to the development of new customers. However, deep into China's SMEs development, we can see, mobile Internet marketing is often used as an auxiliary of traditional marketing, and many SMEs marketing activities tend to have great blindness. And in the era of mobile Internet development, some SMEs in China in the process of development of mobile Internet marketing did not develop and make use of the latest technology, and affected by this, it is difficult for enterprises to grasp the target customer's interest preferences, buying habits and so on, and then increase the blindness of mobile Internet marketing enterprises, resulting in waste of resources.

\section{Strengthen Construction of SMEs Marketing Innovation Strategy System}

\subsection{Training and Introduction of Mobile Internet Marketing Professionals}

Mobile Internet marketing is an emerging industry that requires specialized tal- 
ent as a support for development. In this regard, enterprises in the process of shaping mobile Internet marketing personnel can use a combination of personnel training and the introduction of qualified personnel [11]. On the one hand, for mobile Internet marketers within the enterprise, to strengthen the training of personnel. In the formulation of training content, we must give full consideration to the development needs of internal talents, such as deepening their mobile Internet marketing awareness, training them mobile Internet technology. On the other hand, with the actual development of internal enterprises, actively introduce mobile Internet marketing personnel. In this regard, companies can employ the relevant professional graduates, such as marketing, e-commerce category and so on. For SMEs, on the basis of introducing talents, they need to further train their talents and urge them to translate their theoretical knowledge into realistic marketing capabilities.

\subsection{Update the Concept of Mobile Internet Marketing}

By the impact of the development environment of mobile Internet, the traditional marketing concept in the past has been difficult to effectively lead the progress of SMEs. Different from the traditional marketing model, enterprises need to base their mobile Internet marketing perspective on the development of mobile Internet to actively tap the target customers to achieve economic efficiency improvement. In this regard, SMEs in our country need to update the concept of mobile Internet marketing in time to modern market demand, and actively absorb all the information that is conducive to marketing, such as the development of mobile Internet-related new technologies, new technology and so on, to actively carry out mobile Internet marketing.

\subsection{Use of the Internet Delivery Precisely}

In the era of mobile Internet, SMEs in China have the conditions to develop precision marketing. Because various mobile smart devices are developed, the ways and channels for enterprises to obtain customer information also appear diversified [12]. For example, enterprises can use App, WeChat platform, or through Third-party agencies, combined with the actual development of their own business, based on customer acquisition of information, to further implement the precise delivery of ads. In addition, companies can also take advantage of WeChat public platform and third-party agencies in the product sales activities. The precise placement of advertisements can help customers to gain a deep understanding of the products and services of the enterprises, and the promotion of product sales activities further promote the business transactions. And it should be noted that the development of mobile Internet marketing companies need to effectively achieve a series of pre-sales consultation and after-sales service process, and WeChat public platform is well meet the needs of business development. It promotes customer experience and improves the efficiency of corporate marketing. 


\subsection{Use of Internet Tools to Build Core Competitiveness}

SMEs' capacity to build core competitiveness should be enhanced. They need to recognize that their awareness of the Internet + needs to be strengthened, and to know their own shortcomings. And then they need to attract Internet talent and marketing personnel to improve their technology. The advantage of traditional labor-intensive enterprises, today, is declining. SMEs should create their own unique differentiated value for the company's actual products, if there is no ability to disrupt the product innovation. It is also the embodiment of its core strength. Soft promotion, APP promotion, public number marketing are also a kind of minimal innovation for the enterprise, they are also core competitiveness of the enterprise. In the era of mobile Internet, fans is a considerable economic profit, based on the customer. The details of the ultimate, the perfect experience for customers, products, enhance customer involvement, trigger customers' resonance. SMEs need to captive fans and good brand. Most importantly, the leaders of enterprises should change their mode of thinking, take part in lectures and forums held by the government, take the initiative to visit outstanding enterprises and promote the harmonious development of enterprises [13].

\section{Conclusion}

In practice, influenced by the management system, management concepts and other constraints, there are many problems in formulation and implementation of SMEs marketing strategies in the era of mobile Internet, including lack of marketing concept, lack of professional mobile Internet marketing professionals, and lack of good use of mobile Internet marketing. The inadequacy of the marketing strategy system has severely restricted the sustainable development of SMEs. According to the problems existing in the marketing of SMEs in our country, the marketing strategy optimization of SMEs should be promoted in the aspects of cultivating and introducing mobile Internet marketing professionals, updating the concept of mobile Internet marketing, using Internet precisely delivery and using Internet tools to build core competitiveness.

\section{References}

[1] Wheelen, T.L. and Hunger, J.D. (2011) Concepts in Strategic Management and Business Policy. Pearson Education India.

[2] Doole, I. and Lowe, R. (2008) International Marketing Strategy: Analysis, Development and Implementation. Cengage Learning EMEA.

[3] Hungerland, F., Quitzau, J., Zuber, C., Ehrlich, L., Growitsch, C., Rische, M.C., et al. (2015) The Digital Economy (No. 21e). Strategy 2030-Wealth and Life in the Next Generation.

[4] Sokoto, A.A. and Abdullahi, Y.Z. (2013) Strengthening Small and Medium Enterprises (SMEs) as a Strategy for Poverty Reduction in North Western Nigeria. American Journal of Humanities and Social Sciences, 1, 189-201.

[5] Banister, D. and Stead, D. (2004) Impact of Information and Communications Technology on Transport. Transport Reviews, 24, 611-632. 
https://doi.org/10.1080/0144164042000206060

[6] Duan, H., Han, X. and Yang, H. (2009) An Analysis of Causes for SMEs Financing Difficulty. International Journal of Business and Management, 4, 73.

https://doi.org/10.5539/ijbm.v4n6p73

[7] Hoffmann, W.H. and Schlosser, R. (2001) Success Factors of Strategic Alliances in Small and Medium-Sized Enterprises-An Empirical Survey. Long Range Planning, 34, 357-381. https://doi.org/10.1016/S0024-6301(01)00041-3

[8] Latukha, M. (2016) Talent Management in Emerging Market Firms. https://doi.org/10.1057/978-1-137-50606-1

[9] McDaniel, C. and Gates, R. (2013) Marketing Research. Singapore.

[10] Scott, D.M. (2015) The New Rules of Marketing and PR: How to Use Social Media, Online Video, Mobile Applications, Blogs, News Releases, and Viral Marketing to Reach Buyers Directly. John Wiley \& Sons. https://doi.org/10.1002/9781119172499

[11] Armstrong, G. (2009) Marketing: An Introduction. Pearson Education.

[12] Hernando, I. and Nieto, M.J. (2007) Is the Internet Delivery Channel Changing Banks' Performance? The Case of Spanish Banks. Journal of Banking \& Finance, 31, 1083-1099. https://doi.org/10.1016/j.jbankfin.2006.10.011

[13] Ross, D.F. (2016) Introduction to E-Supply Chain Management: Engaging Technology to Build Market-Winning Business Partnerships. CRC Press. 